\title{
The Rhetoric of Results and the Results of Rhetoric: Judicial Writings
}

\author{
Patricia M. Wald $\dagger$
}

\section{WHY WRITE?}

Why do judges write? Why do we not simply decree results in individual cases and, as necessary, announce broader commandments about what the law requires? From where does the imperative come to tell why we rule as we do in every case? ${ }^{1}$

$\dagger$ Judge, United States Court of Appeals for the District of Columbia Circuit; Chief Judge 1986-91. My thanks for help and suggestions to my law clerks Bradley Karkkainen, J.D. 1994, Yale University; Alexandra Edsall, J.D. 1994 Harvard University; Timothy Simeone, J.D. 1994, The University of Chicago; and to my husband, Bob.

1 Judicial opinion writing has roots in both Roman and early English law, though in neither case were there full-blown written opinions. Roman adjudication was divided between the praetor, or magistrate, and the iudex, a lay arbitrator. Upon receiving the pleadings of parties to a lawsuit, the praetor would craft those pleadings into a formula, which instructed the iudex on how to decide the case. The formula was not unlike jury instructions, although it left both questions of law and fact to the iudex, who then decided the case without written record. The Roman jurists-learned statesmen with no official role-were the other main writers of the system. These jurists rendered advice to both litigants and praetors and published treatise-like commentaries describing the resolution of real and hypothetical problems. See Barry Nicholas, An Introduction to Roman Law 1935 (Oxford, 1962).

English opinion writing has its origins in the plea rolls and Year Books. Dating from the early thirteenth century, both the county and the King's courts kept plea rolls-clerk's records that described the pleadings and the outcomes of the cases heard before the court. See Theodore F.T. Plucknett, A Concise History of the Common Law 230-31 (Law Co-op, 2d ed 1936); Joseph Biancalana, Medieval County Courts: A Review Essay, 52 U Cin L Rev 994, 1004 (1983), reviewing Robert C. Palmer, The County Courts of Medieval England: 1150-1350 (Princeton, 1982). Like opinions, the plea rolls encapsulated the decisions of the court. By the last decades of the thirteenth century, the "Year Books" appeared in England. Less formal than the plea rolls, the Year Books were chronological reports, of unknown authorship, containing rough transcriptions of court proceedings. Because they included the arguments made by the lawyers and the reasoning offered by the judge, they offered more of the texture of an opinion than did the plea rolls. See Plucknett, $A$ Concise History of the Common Law at 239-42.

With the advent of print, various reports came into existence, largely written by court reporters rather than the judges themselves. The Reports series, however, was written by Lord Coke himself and covered both his own and others' decisions. By the end of the eighteenth century in England, judges routinely "authorized" certain reports by looking over the draft reports of their decisions prior to publication. Id at 248-49. In the United States, meanwhile, many states in the eighteenth century adopted the statutory requirement that judges write their opinions rather than merely state them orally. See 
Tradition aside, modern judges write opinions mainly for two reasons: first, to reinforce our oft-challenged and arguably shaky authority to tell others-including our duly elected political leaders-what to do. Only in certain states do voters troop to the polls to give judges their proxies to do justice on their behalf, and federal judges cannot even be removed except through a cumbersome impeachment process reserved for extraordinarily bad behavior. Judges are like family; though alternately beloved or resented, the people are bound to us through thick and thin. One of the few ways we have to justify our power to decide matters important to our fellow citizens is to explain why we decide as we do.

The second reason we write opinions is to demonstrate our recognition that under a government of laws, ordinary people have a right to expect that the law will apply to all citizens alike. Optimally, that means that more than eight hundred federal judges should interpret the same laws in the same way. Since this will not likely happen by itself, the system creates devices to impose consistency and correct the judges who "err": primarily a hierarchy of judges in which the upper tier judges the lower tiers. Even to approach a goal of consistency, litigants, lawyers, reviewing judges, the press, and ordinary citizens need to know why a particular judge came to a particular decision in a particular set of circumstances. That way, they can decide if the law is really a seamless web or irreparably snagged by a bunch of clumsy knitters who can't take directions.

Of course, judges write for other reasons too. Transplants from academia may feel irresistibly driven to communicate their intellectual processes and products to the world. Refugees from the world of politics and public affairs write to persuade their colleagues and the public that they are moving law in the right direction. Some judges write for the personal gratification that comes from being quoted, cited, and republished in law school casebooks, with the side benefits of invitations to lecture, write in law reviews, and-not to be sneered at-attract the best and the brightest law clerks. Ambitious judges may write in hopes of promotion to higher judicial office, although my own view is that political aides do not read judges' opinions to find the most talented candidates but only to screen for smoking guns that might spell confirmation trouble. 
The symbiotic relationship between judicial style and substance must be appraised against all these institutional and personal reasons why judges write, but the quests for credibility and consistency, two goals not always in harmony, are the most critical. Some recent developments have the potential for undermining both goals. American judges write fewer opinions every year in proportion to the cases we decide. Facing rising caseloads, we are told to be more selective as to which cases we write about for the law books. ${ }^{2}$ The rest will likely receive a few sentences of rationale with maybe a citation or two; they will be memorialized, if at all, only in computer data banks, rather than in the red, gold, and black volumes of the Federal Reporter; they cannot be cited as authority for any proposition, rendering them in effect a class of legal "untouchables." Only the parties and their lawyers read them, and for the most part, law clerks, not judges, draft them. The rhetoric of these cryptic statements is typically dismissive in tone: "The precedent is clear"; "there is nothing new here"; "this is a garden variety dispute." Often the Scroogelike verbiage sounds a complaining tone: "You shouldn't be bothering us"; "how many times do we have to tell you?" The style is typically banal: boilerplate nostrums. The message comes through clearly to the losing party: "You never had a real chance, and we have gone to the least possible trouble to tell you why."

The decision to consign a case to "no-opinion" status invariably signals affirmance of the decision below and an implied assumption that nothing new, provocative, or controversial will be said in the brief memorandum or order disposing of the case. The vast number of these unpublished opinions are turned out within hours or days of argument or conference.

Due to the pressure of accelerating caseloads, the majority of federal cases now get this unpublished treatment. ${ }^{3}$ Many would have been the subject of full-fledged opinions a few decades ago.

2 See Committee on Long Range Planning, Judicial Conference of the United States, Proposed Long Range Plan for the Federal Courts recommendation 39d at 64 (1995) ("Proposed Long Range Plan") ("Opinions should be restricted to appellate decisions of precedential import.").

3 The Administrative Office of the United States Courts reports that for the year ending September 30, 1994, federal appellate courts issued 7,019 published opinions and 20,114 unpublished opinions. The percentage of unpublished opinions terminating cases on the merits is $74.2 \%$. In the D.C. Circuit it is $67.3 \%$; other circuits range from a low of $46.6 \%$ in the First Circuit to a high of $86.6 \%$ in the Fourth Circuit. All but the First and Seventh Circuits dispose of more than a majority of cases by unpublished opinions or orders. Administrative Offiice of the United States Courts, Reports of the Proceedings of the Judicial Conference of the United States table S-3 (on file with U Chi L Rev). 
When I came onto the D.C. Circuit in 1979, we rarely if ever disposed of a criminal appeal without an opinion; now we handle $72 \%$ that way. ${ }^{4}$ Not surprisingly, perusal of these "unworthies" shows that some, in fact, deal with issues not clearly controlled by prior precedent and some, contrary to the genre, require ten to fifteen typescript pages of highly condensed and largely conclusory reasoning to come to judgment.

It is the judges-sometimes only the assigned author-who decide whether to write a full opinion. Some courts establish criteria to guide the decision, but in my experience the criteria are vague and infinitely maneuverable. In a study of the D.C. Circuit's unpublished decisions several years ago, a bar committee, applying our own written criteria, questioned the decision not to publish in 40 percent of the cases. I would guess the number would be much higher now.

Lawyers and commentators regularly raise the specter of "secret justice," "unequal justice," and "sloppy justice" stemming from the growing popularity of unpublished dispositions, particularly in appellate courts, which are supposed to be in charge of keeping the law tidy. ${ }^{5}$ Still, no one has solved the numbers dilemma that spawned the surge of unpublished opinions. Time does not allow for the same careful, thoughtful analysis and writing to be poured into all cases. But a double-track system allows for deviousness and abuse. I have seen judges purposely compromise on an unpublished decision incorporating an agreed-upon result in order to avoid a time-consuming public debate about what law controls. I have even seen wily would-be dissenters go along with a result they do not like so long as it is not elevated to a precedent. We do occasionally sweep troublesome issues under the rug, though most will not stay put for long. But what is the alternative?

There is indeed a worrisome "lost horizon" aspect to no-opinion dispositions. Even when judges agree on a proposed result after reading briefs and hearing argument, the true test comes

4 Of 184 criminal appeals terminated on the merits by the Court of Appeals for the D.C. Circuit during the year ending September 30, 1993, 115 received oral argument and 69 did not. Administrative Office of the United States Courts, 1993 U.S. Courts: Selected Reports AI-3 table B-1. Cases that are not argued seldom, if ever, result in published opinions. But argued cases also result more and more in unpublished opinions. A hand count of 213 terminated criminal appeals in the D.C. Circuit from October 1, 1993, to September 30, 1994, showed 48 voluntary dismissals or dismissals for want of prosecution, 118 terminated by unpublished orders or memoranda, and 47 published opinions.

${ }_{5}$ See National Classification Committee $v$ United States, 765 F2d 164, 172-73 \& $n 2$ (DC Cir 1985) (Wald separate statement) (citing criticism of practice). 
when the writing judge reasons it out on paper (or on computer). That process, more than the vote at conference or the courtroom dialogue, puts the writer on the line, reminds her with each tap of the key that she will be held responsible for the logic and persuasiveness of the reasoning and its implications for the larger body of circuit or national law. Most judges feel that responsibility keenly; they literally agonize over their published opinions, which sometimes take weeks or even months to bring to term. It is not so unusual to modulate, transfer, or even switch an originally intended rationale or result in midstream because "it just won't write." But writing to explain a preordained result with no concern for its precedential effect under a self-imposed time constraint of hours is something else entirely, inviting no backward looks or self-doubt. Rhetoric will always be tied to import and permanence, and its absence in unpublished decisions signifies that they are the product of a different and much-abbreviated decision-making process.

Is this absence of rhetoric really serious? What does it matter if the result is right? (In most cases it probably is.) Our English forebears did and do announce decisions from the bench with no off-the-bench deliberative time. This is still common practice in many state courts that suffer the heaviest flood of cases, and our district court judges regularly make oral rulings in the middle of trials to keep things moving. Absence of rhetoric is principally an appellate court problem. ${ }^{6}$ The higher a court's place in the judicial hierarchy, the more important it is for that court to rationalize its results. What would the reaction be if the Supreme Court started to make bench rulings, or decide cases by unpublished orders? Some might say it already does much the same, by denying certiorari in thousands of cases each year, but there the effect ordinarily is to leave a lower court's opinion in place. Yet federal courts of appeals are the courts of last resort for almost forty-nine thousand appeals every year; ${ }^{7}$ the Supreme Court currently decides less than one hundred. Indisputably the thirteen courts of appeals declare far more federal law affecting far

- The Illinois Supreme Court has placed a controversial "cap" on the number of opinions that the state intermediate appellate courts can issue each year, ranging from 150-750 opinions, as well as a twenty-page limit on the length of majority opinions and a five-page limit on dissents and concurrences. Mark Hauser, Illinois Caps Appellate Opinions: Faced with an 'Avalanche of Opinions,' Court Refuses to Change Unique Order, ABA J 36-37 (Dec 1994).

7 Proposed Long Range Plan at 14 table 4 (cited in note 2). See also Administrative Office of the United States Courts, 1993 U.S. Courts at AI-3 table B-1 (cited in note 4). 
more citizens than the Supreme Court does. We need to apply inner controls to make sure we are doing it right.

In the end, the question is whether it is possible for appellate courts to slip in and out of two different modes of decision making, one rhetorical and the other nonrhetorical. Can overworked judges be seduced too easily into preferring the easier, nonrhetorical route, especially in close cases? In my own D.C. Circuit, the wide gap between the number of published and unpublished opinions written by different judges gives pause. Some clearly prefer the unpublished route, or at least, evaluate many more cases as appropriately consigned there than do others. One of our most prominent judges a few years ago authored twentythree published opinions and thirty-one unpublished opinions for the court, while an equally distinguished colleague authored thirty-four published and only three unpublished opinions. All judges on our court sit on the same number of cases annually.

The delivered wisdom is that we use the no-opinion route only in the clear-cut cases. That may have been so in the past, but is not so clear anymore. More and more issues are being decided without opinion, almost in arbitral fashion (arbitrators need give no reasons, just bottom lines). Possible alternatives, such as per curiams-short on rhetoric but nonetheless of precedential value and requiring minimally responsible rationales-have been largely bypassed. There ought, in my view, to be periodic overviews of which kinds of cases get sent down one track rather than another. Danger signals include the presence of obviously difficult issues or the predominance of certain kinds of cases (for example § 1983 prisoner cases) on one track, inconsistencies between published and unpublished results and rationales, and widely differing rates of published and unpublished opinions among different judges.

It may indeed be possible to have individual justice without judicial rhetoric. But is it possible to have reasonably consistent justice administered by hundreds of judges for millions of people without any permanent record as to why cases come out one way or the other? Surely not. Justice, like education, can be administered on different tracks, but the tracking system must be carefully and continually watched lest arbitrary factors skew the system, which could already be happening. The law is coming to be defined by the issues and situations the judges decide to write about, not as in the old common law by the accretion of all the results in all the situations actually presented to the judges. If 
that fault becomes too wide, the ground on which judicial legitimacy rests can be disastrously shaken.

\section{CONSTRAINTS ON JUDICIAL RHETORIC}

If judges' druthers prevailed, opinion writing would go like this: read briefs, listen to argument, confer with colleagues, do research, organize thoughts and material, begin writing-with a tentative tilt but not a permanent fix toward a particular result. At each step the judge would recanvass her building blocks to make sure they were solid in their own right and locked together in a systematic design. She would go where the facts, logic, and that sense of ultimate rightness-call it conscience, moral compass, or as Justice Holmes did, his "can't helps"-took her. And like a gifted novelist, she would let the characters and the plot take on a life of their own, drawing her along toward one irresistible conclusion.

A Platonic guardian, or perhaps a single Chancellor in Equity, might so dispense justice; a modern-day appellate judge cannot. In virtually all cases, the judge shapes her raw material. She picks her rhetoric to foreshadow the result. Institutional constraints in the judging process require it.

\section{A. The Collegial (AKA Committee) Nature of the Undertaking}

The author of a majority opinion in an appellate tribunal writes "for the court." At least one other judge must concur in the opinion for it to have precedential status and for future courts to follow its reasoning. If two judges can agree only on a result, not a rationale, they issue a per curiam setting out the judgment, and individual judges give their individual reasons. This is a frustrating outcome, assiduously to be avoided. It signifies an inability of even two judges to agree what the law is or should be; it sends conflicting signals to the bar or the public as to how cases will be decided in the future; jurisprudentially speaking, it's a wash. Predictably, then, most judges will compromise their preferred rationale and rhetoric to gain a full concurrence from other members of the panel. In an appellate court composed of strong-minded men and women of different political and personal philosophies, consensus is a formidable constraint on what an opinion writer says and how she says it. Her best lines are often left on the cutting room floor.

Opinion writing among judges of widely disparate views and temperaments is, like governing, the art of the possible. Certain 
scenarios occur regularly. If alternative rationales are available to support a result, the one that can garner a majority of judges will be chosen, even if it is not the writer's preferred one. But once a majority is assured for a rationale, further compromises to secure more votes or unanimity may comfortably be rejected. A panel of two or three like-minded judges, confident of the backup support of a majority of the whole court (should the case be taken en banc), will often break new ground or recanvass already settled law, although a more modest rationale would satisfy more of the judges. In the mid-1980s, then-Judge Bork wrote a highly controversial opinion in a gays-in-the-military case interpreting a half dozen or so Supreme Court holdings on the right to privacy. The opinion provoked strong protest by a minority of the court desiring to rehear the case en banc, although it seems quite clear that a narrower, fact-based ruling upholding the Navy's sanctioning of an officer's homosexual conduct on base would have evoked no contest at all. ${ }^{8}$ Similarly, when the judges on the panel agree on most but not all of the issues in a case, the opinion writer will usually strive to fashion a rationale that does not even discuss the disputed matter, or buries it in a coverall phrase like "other issues raised by the appellant do not merit further discussion." In such cases, the writer for a precarious majority has no wish to start other panel members down the road of a special concurrence or partial dissent, lest the whole compromise unravel. So the writer may sacrifice full treatment of all nonfrivolous issues properly before the court. Containment is the watchword.

This kind of jurisprudential politics is a constant on appellate courts. On the whole, judges are more absorbed in doctrines than in individual cases; they like to see their favorite doctrinal flowers grow and flourish, and conversely, they rejoice when doctrinal weeds or aberrant strains wither and die. Thus, much bargaining goes on among judges about the grounds for a decision.

Standing law, which determines which plaintiffs can have access to the court to settle disputes, is an outstanding example of a doctrine generously nurtured in the D.C. Circuit. For well over a decade, our judges have been jousting over its requirements, often raising standing objections on their own where the parties have not done so, and in general taking the court down a road of more limited access. Article III standing is, of course, a

${ }^{8}$ Dronenburg $v$ Zech, 741 F2d 1388 (DC Cir 1984); Dronenburg $v$ Zech, 746 F2d 1579 (DC Cir 1984) (opinions on denial of rehearing en banc). 
threshold jurisdiction requirement for federal courts, albeit a mandate that can be interpreted either rigidly or flexibly. Witness an en banc case decided in 1988 where the full D.C. Circuit split five to five as to whether the plaintiffs had standing ${ }^{9}-a$ spirited debate filling no less than forty-five pages of the Federal Reporter. Our court has, however, transcended Article III constitutional standing and developed a flourishing "suitable challenger" doctrine of prudential standing all its own that dismisses cases meeting Article III criteria but which the court feels should be brought by other kinds of plaintiffs. ${ }^{10}$ Similarly, we have pioneered a "heightened pleading" standard for $\S 1983$ civil rights cases that demands more than the normal Federal Rules notice pleading in suits against individual government officials. ${ }^{11}$ These access doctrines are favored by a majority of our judges and strongly disfavored by others, who will bargain aggressively to decide cases on other grounds. In a close case, a would-be dissenter may agree to go along with a disfavored result if a disfavored rationale is avoided.

Collegial oversight intrudes into opinion writing in ways other than selection of basic rationales. It can influence the choice of case precedent to be relied on or even cited. Certain Supreme Court rulings are so distasteful to some lower court judges that they will ask for their excision in a colleague's opinion if there is another more acceptable precedent for the same general proposition; Korematsu $v$ United States ${ }^{12}$ and Rust $v$ Sullivan ${ }^{13}$ are two examples of such pariahs. Citations to treatises, articles, and commentaries, whose authors or views are unacceptable to some judges, may be discouraged as well. Even an opinion writer's attempts at a literary allusion or humor may be sacrificed in the wake of a colleague's resistance. I have the sense that this kind of line-item veto is more prevalent now than when I clerked forty years ago. Learned Hand is said in Gerald Gunther's biography to have curbed a colleague's tendency to be "excessively picayune in criticizing others' draft opinions," at one time admonishing him that "[t]he practice here has never been to go over the opinions with as much care as you have and I am

9 Center for Auto Safety $v$ Thomas, 847 F2d 843 (DC Cir) (en banc), vacated and original petition for review denied, 856 F2d 1557 (DC Cir 1988),

${ }^{10}$ Hazardous Waste Treatment Council $v$ Thomas, 885 F2d 918, 924 (DC Cir 1989).

"Siegert $v$ Gilley, 895 F2d 797, 800-02 (DC Cir 1990), aff'd on other grounds, 500 US 226 (1991).

12323 US 214 (1944) (Japanese interment).

${ }^{13} 500$ US 173 (1991) (abortion gag rule). 
rather afraid that it will annoy Hough [a Second Circuit judge] a little ...."14 As for himself, Hand said he accepted colleagues' opinions "as they came unless there was some clear statement of law such as I could not join in. [I] seldom find another opinion which says the thing as I should have. ${ }^{315}$ Although my own boss, Judge Jerome Frank, was wont to write in an extravagant manner, his opinions replete with lengthy excursions into the origin and worthiness of policies that drove the law, and generously sprinkled with references to other disciplines such as linguistics and psychology, Learned Hand almost invariably concurred in them without reservation or requests for deletions.

$\mathrm{My}$ experience in recent years is that my colleagues of all ideological bents scan others' opinions carefully for any hint of gratuitous approval of doctrinal views to which they do not subscribe or unnecessary criticism of those they do. I have also known judges who edit opinions to conform to their own style preferences, an irritating habit in my view. Colleagues who are in agreement with the author of a draft opinion in the instant case but who are more often on the opposite side can be especially finicky about rhetorical flourishes or announcements of grand principles, lest they be thought to have "converted" or been ensnared by the author's semantic manipulation. Thus, judges generally in the minority on a court who find themselves assigned to write majority opinions are often subjected to strong pressures to "stick to the facts," "decide this case only," and avoid all generalities or expressions of high-flown precepts. In the press to get an opinion accepted and into circulation, the writing judge will usually sacrifice her own rhetorical preferences to hard-pressed "suggestions" of her colleagues. Rhetoric is the hostage of judicial politics. Minority judges must find their rhetorical outlet mainly in dissents.

\section{B. Personal Relationships on the Court}

Justice William Brennan, Jr., once remarked, "in an institution this small, personalities play an important role. ... How those people get along, how they relate, what ideas they have, how flexible or intractable they are, are all of enormous significance." Judicial rhetoric, too, is influenced by relationships.

\footnotetext{
14 Gerald Gunther, Learned Hand: The Man and the Judge 298 (Knopf, 1994).

15 Id (alteration in original).

${ }_{16}$ Jeffrey T. Leeds, A Life on the Court, NY Times Mag 74 (Oct 5, 1986).
} 
Whether a majority opinion treats a dissenter caustically, humorously, or gently will often depend upon whether the two judges are historic allies or personal friends, uncharacteristically separated in this one case, or lifelong foes for whom each case represents a new arena in which to settle old scores. An astute reader of judicial writing recognizes the difference right away. One mark of an old animosity is repeated identification of the "enemy judge" by name; I once counted my own name (or title as Chief Judge) used over two dozen times by a majority in a case in which I was dissenting. Friendly fire, on the other hand, refers instead only to "the dissent" or "our dissenting colleague," elevating the dispute to a more impersonal plane. An entire line of cases attacked by a majority or dissenting opinion may be identified by the name of the case known to be authored by the antagonist judge, while other cases with identical holdings written by friendlier judges are allowed to travel incognito. If thereby a whole line of cases is overruled or severely impugned, the defeat will be identified with the judge who wrote the named case, although it may in fact have simply been following the precedent of an earlier opinion by a friendly judge. Sounds sophomoric-it is-but it happens. The temptation can be overpowering for a writing judge to give vent to longstanding frustrations with a colleague by pejorative references to his point of view as "hopelessly muddled"; "reminiscent of Marie Antoinette's advice to let them eat cake"; "beyond all reason"; "pure speculation and fantasy"; "a Linnaean leap"; "shoddy"; an "ad hoc judgment"; "devoid of precedent"; "ungoverned by law." Chronic antagonists relentlessly dig out old cases or even old law review articles to show inconsistencies in each other's positions. Tensions build on a court as judges of all stripes work together over decades. The result is often, unconsciously or even consciously, to let their heartfelt likes or dislikes for other judges seep into their rhetoric.

To a lesser degree, appellate opinions reveal the writers' attitudes toward the particular district judges whose opinions are reviewed. The occasional lapses of those trial judges with reputations for care and sound judgment are accepted more in sorrow than in anger, while those considered hipshooters or of markedly different judicial philosophies than the reviewing judges may be treated more harshly. Rhetoric apart, there is no question the reviewing judges' perception of the ability of the trial judge counts heavily. If they consider him capable and generally astute, they will try harder to uphold him, especially in close cases. Trial judges are given wide berth in their assessments of witness credi- 
bility, in their judgments on admission of evidence, and in their instructions to the jury. Where errors are asserted, a trial judge of excellent repute will be given the benefit of every doubt. Even when he has clearly erred, he will be treated as though he made an understandable mistake; a judge less charitably viewed will be told in no uncertain terms what he did wrong, and often admonished not to do it again, sometimes even with references to other past mistakes. He may be identified by name, though early on I was told the prevailing decorum was that, if we upheld a trial judge, we referred to her by name; if we reversed the judge, we left him anonymous.

Finally, the judge's feelings about counsel may influence the rhetoric in the opinion. Some judges are patently, even cruelly, intolerant of lawyers' slips, quick to identify and chastise their errors; other judges stick to the legal issues with negative comments on counsel's competence reserved for only the most egregious errors. Having been a courtroom advocate for many years myself, I can attest to how horrific an experience it is to be personally criticized in a judicial opinion. In some cases it may be deserved, but for myself I try to refrain except where counsel has shown inexcusable negligence or edged toward malpractice. Eter$\mathrm{nal}$ condemnation in the pages of F3d is a strong sanction. Nonetheless, some judges will indulge in it on the basis of a testy exchange with counsel at argument or an impression from this and prior cases that the lawyer is just not up to par. Unless the reader knows better, she may take away notions that the victims of the judge's wrath are extraordinarily bad actors. That is not necessarily so. Judges' hot-button temperaments show up frequently in these side comments. After a while, their colleagues accept it as part of the territory, but one has to wonder whether district judges or counsel are so complacent.

Although judges may indeed develop immunity to internecine barbs over the years, the public perception such barbs produce can only demean courts. A recent article in the American Bar Association Journal by a distinguished practitioner and former Deputy Solicitor General scored the escalation of "scathing and snide ripostes" among Supreme Court Justices in recent times. ${ }^{17}$ His account, supplemented by some examples from my own reading, produce an astonishing catalogue of derision by one Justice of another: "misleading," "just not true," "facile," "simplistic,"

17 Philip Allen Lacovara, Un-Courtly Manners: Quarrelsome Justices are no Longer a Model of Civility for Lawyers, ABA J 50, 50 (Dec 1994). 
"contrary to common sense," "breathtaking steamrolling," "as blind to history as to precedent," "less a legal analysis than a manifesto of socialism," "a hodgepodge of criteria," "myopic focus," "a nonchalant conclusion," "turning the Commerce Clause on its head," "abandoning history and test as guides," "a highly inaccurate portrayal of this case," a "messianic insistence on a grim sink-or-swim policy of laissez-faire economics." Jibes that another Justice "ignores," "fundamentally alters," or "nullifies" crowd the pages. Regular dissenters such as Justice Scalia are particularly prone to stylish stabs. A few illustrations:

- Characterization of a majority opinion rejecting gender as a basis for peremptory jury challenges as "an inspiring demonstration of how thoroughly up-to-date and right-thinking we justices are" and "how sternly we disapprove the male chauvinistic attitudes of our predecessors."

- Assertions that another majority opinion "displays once again that our acceptance of the supposed teachings of legislative history is more sporadic than our professions of allegiance to it."19

- And a final jibe that, "Today the ad hoc nullification machine claims its latest, greatest, and most surprising victim: the First Amendment." 20

The same ABA Journal article cites, as worst-case examples, two Justices "[o]nce expected to become jurisprudential allies, [who] today [ ] rarely say a civil word about one another in their opinions."21

Lively reading, perhaps; good for the courts, no.

Finally, the judge's relationship to his law clerk(s) may vitally affect the rhetoric in his opinion. It is an ill-kept secret that law clerks often do early drafts of opinions for their judges. Some judges confine themselves to editing clerks' prose; some judges give their original prose to clerks to edit. Some judges go over and over successive drafts, focusing on every word and phrase so that the final product is essentially theirs; some simply consume

${ }^{18}$ J.E.B. v T.B., $114 \mathrm{~S}$ Ct 1419, 1436 (1994) (Scalia dissenting).

${ }_{19}$ Posters $N^{\prime}$ Things, Ltd. $v$ United States, 114 S Ct 1747, 1756-57 (1994) (Scalia concurring in the judgment).

${ }^{20}$ Madsen $v$ Women's Health Center, Inc., 114 S Ct 2516, 2535 (1994) (Scalia concurring in the judgment in part and dissenting in part).

21 Lacovara, ABA J at 52 (cited in note 17). 
the clerk's draft opinion as a whole to see if it is digestible and do not fuss with language. The more symbiotic the judge-clerk relationship is, the more opinion rhetoric that will originate with the clerk. Most judges I know let clerks write first drafts of opinions after discussing a proposed rationale and framework. After the clerk's first draft comes in, several things can happen: (1) the clerk may be told to go back to square one and do a new draft; (2) the clerk's draft may undergo a mild edit by the judge and be put into circulation; or (3) the judge may take over the opinion and either substantially revise it or do a total rewrite and carry it through to completion. In any of these scenarios, a small to substantial part of the rhetoric in the final opinion will come out of the clerk's computer. Clerks vary in writing ability and usually stay with a judge for only a year. A judge puts her own stylistic gloss on a clerk's work product, but often does not change its fundamental organization or even tone. If the clerk's rhetoric is smooth or catchy, the judge is apt to keep that too. Clerks are often erudite, but they are also young and typically hardly out of the academic nest. It may be the judge's tenth or fifteenth or thirtieth year on the court; it is the clerk's first and last.

The clerk's contribution to judicial rhetoric has been the subject of much critical comment. He who wields the pen on the first draft, it is said, controls the last draft. The length and repetitiveness, the obscurity of some opinions is laid by many at the feet of the clerk sorcerers. Some of the criticisms may be warranted, but in my experience, judges who write every word of their own opinions (except for a few certifiable geniuses) do not produce works of markedly greater clarity, cogency, or semantic skill. The opposite is more likely true. The judge's essence is in determining the result in an individual case, the grounds for reaching it, and drawing out from his superior wisdom and life experience its implications for future cases. If the clerk can take that essence and find precedent to support it, add some insights of her own, and put it all into a coherent literary for, easily understood by an ordinary reader, nothing is lost and much gained. It is the judge's ultimate responsibility, of course, to insure it all works out that way, rather than ending in some dense and fulsome compromise. But I for one would not return to the days when law clerks sharpened pencils and checked citations; the present system for deciding cases could not sustain that development. Even Holmes or Hand could not likely go it alone in the current climate. Few judges I know are so disarmed by the rhetoric of their one-year-at-a-time clerks that their substantive judg- 
ments are eroded, and the readability of an opinion can be enhanced by a really talented clerk who turns out a nice phrase-or on occasions a memorable one.

\section{Time and Volume}

My son-in-law stopped writing a weekly column in a major newspaper after five years. At that point, he said, it had become a chore and he felt his creative juices drying up. He needed a rest from the pressure of deadlines. Obviously many talented people write steadily, unrelievedly throughout their careers, but others must pace themselves. They have fertile periods and periods of drought, and their writings flow or ebb accordingly. (News reporters may be an exception; they have daily beats to cover, rain or shine, but at least theoretically they report happenings, not make judgments on them.) No such options exist for judges. We are required to produce roughly the same number of opinions-in my own case forty to forty-five-year in, year out, and we do not choose the subject matter. It is not uncommon, then, for our prose, even certain idiosyncratic expressions, often to become frozen, for writing styles to reveal personalized boilerplate. The same issues recur in cases over the years, and we tend to think about them in the same ways. Often I discover I am plagiarizing from my own earlier opinions without realizing it. A judge, recognizing a familiar fact pattern, goes into automatic pilot. It takes a brand new issue about which one feels strongly or which excites one intellectually to provoke fresh new modes of expression.

And, of course, there are time limits. A judge does not have the luxury to spend substantial extra time savoring a line or phrase; the litigants want judgments, not rhetoric, so they can get on with their lives. Forty published opinions a year, some extremely lengthy, along with reading briefs, listening to arguments, ruling on motions, reading other judges' opinions, does not allow the luxury of setting the case aside and coming back to it in a month because you have writer's block; you wade through to the end, no matter how paralyzed your pen. The liveliness and originality of prose suffers during these periods of semi-impotence, which virtually every veteran judge experiences at some time or other. 


\section{III. "Framing THE CASE": TAKING LIBERTIES WitH ConstraintS}

A. "Finding" the Facts

The conventional wisdom is that the "Facts" portion of an appellate opinion merely recites neutral, predetermined "facts" found by the lower court or an agency. After all, the appellate court has no factfinding authority of its own. Yet nothing could be farther from the truth. When an appellate judge sits down to write up a case, she knows how the case will come out and she consciously relates a "story" that will convince the reader it has come out right. In the last century the fact-"spinning" function of opinions has become much more important; in the old nineteenth century opinions each side's claims were set out in detail. Now there is only one account of the "facts," unless, of course, a dissenting judge provides a second one. When that happens, the contrast is often like a replay of Rashomon-two opinions talking about two totally different cases. Because, however, in the usual case there is only one set of facts given, appellate authors have the liberty to engage in much "storytelling" work in their opening fact section.

Constructing the facts is a wholly legitimate element of the appellate judge's job. After all, one cannot simply reprint the record of the trial below, and the task of interpreting and condensing the record requires that the judge frequently dip his pen into the well of rhetoric. While actual findings by the court or the agency below operate as an outer constraint on appellate decision making, appellate judges nonetheless enjoy great leeway to massage and mold the facts in their retelling of the story. This is not just a matter of being selective about which facts to emphasize (or even to mention), but also a matter of characterization; the facts can-and indeed must-be retold to cast a party as an innocent victim or an undeserving malefactor, to tow the storyline into the safe harbor of whatever principles of law the author thinks should control the case.

Compare the factual accounts in the majority opinion of Judge Silberman and the dissenting opinion which I wrote in the D.C. Circuit's recent en banc decision in Steffan $v$ Perry, the gay midshipman case. ${ }^{22}$ The majority recounts the conflict between the dismissed sailor and Navy regulations in terms that describe a run-of-the-mill, "close-enough-for-government-work" equal pro-

${ }^{22} 41$ F3d 677 (DC Cir 1994) (en banc). 
tection case, that will pass muster under the rule that a government regulation is permissible as long as it gets the right outcome in more cases than not. The facts assembled in the dissent-taken from the same record-align the case much more closely to the category of cases that say our most cherished traditions of individual liberty and the rule of law forbid the government to punish mere thoughts or to infer a likelihood of prohibited conduct therefrom.

The majority's discussion of the background of the case begins with an impersonal statement: "Midshipmen enrolled in the Naval Academy are subject to at least two sets of regulations relevant to homosexuality.... ${ }^{\text {23 }}$ There follow two pages describing in dry bureaucratic detail the Navy's regulations disqualifying homosexuals from service before Joseph Steffan's name appears for the first time. The dissent, in contrast, begins by telling a human story describing Steffan's outstanding performance at the Naval Academy; ${ }^{24}$ the regulations with which the majority opens its opinion do not appear until more than a quarter of the way through the dissenting opinion. ${ }^{25}$

An even starker difference in the techniques employed by the opposing factions of the court in framing Steffan's case concerns their presentation of the earlier stages of the litigation. The majority limits its discussion of the procedural background of the case to a footnote, stating that its decision followed the full court's decision to vacate an earlier panel's ruling for rehearing en banc. ${ }^{26}$ The dissent devotes nearly half of its discussion of the case's background to describing the earlier proceedings at the district court and appellate levels. ${ }^{27}$ It thereby suggests that the majority's treatment of the case broke with the parties' understanding of the case and the views of the district and appellate courts at earlier stages of the litigation.

In describing the "facts," judges are also heedful of relevant or controlling precedent; they will emphasize the facts in the instant case that distinguish it from unhelpful precedent as well as facts that fit earlier helpful precedents.

Do these judicial "storytelling" techniques drive the outcome of the case? Probably not; more likely the opposite. Judges decide

\footnotetext{
23 Id at 682.

24 Id at 701 (Wald dissenting).

25 Id at 706-07.

25 Steffan, 41 F3d at 684 n 2.

27 Id at 703-04 (Wald dissenting).
} 
outcomes, and then tell the story in a way that makes the outcome look like a perfectly logical and necessary consequence of the law, handed to us from above, as applied to the facts, handed to us from below. Understand, I do not mean to suggest there are not real constraints in the process itself: judges cannot run roughshod over the factual findings of lower bodies or the relevant law. Their discretion in deciding the outcome in the first place is constrained by the degree to which they can (reasonably) mold the facts and the law to tell a coherent story. But skill in judicial storytelling definitely enlarges the scope of judicial discretion.

Perhaps the most dramatic instance I have encountered of the court's power to dictate an outcome through its characterization of the record came in the case of United States Information Agency $v K r c{ }^{28}$ which involved the United States Information Agency's ("USIA") termination of an acknowledged homosexual from the Foreign Service. After dismissal, the officer appealed to the Foreign Service Grievance Board, which overruled the agency on the ground that no misconduct had been shown and ordered reinstatement. On the government's appeal to the district court, the court set aside the Board's order and dismissed Krc's other claims. On the appeal from the district court's dismissal, our court said that because the USIA's decision was made on the basis of Krc's sexual orientation, not on the basis of his sexual conduct, the Foreign Service Grievance Board, which could hear only "misconduct" cases, did not have jurisdiction. On the basis of this "fact" the court remanded to the district court for a decision on whether sexual "orientation" was a constitutionally valid ground for dismissal. The trial court again ruled against $\mathrm{Krc}$. On appeal from this decision, a different panel of the court found on the same record (no new evidence had been adduced in the second hearing) that Krc's sexual orientation was superfluous because the discharge was based on his indiscreet conduct along with "undisclosed" secret information about him. Dissenting, I objected that:

The majority's new causal conclusion flatly contradicts our earlier finding that Krc's discharge was not based on misconduct because it was based on his sexual orientation. I would have thought that finding came close to, if indeed it did not actually qualify as, the law of the case; certainly it

${ }^{28} 989$ F2d 1211 (DC Cir 1993), cert denied, 114 S Ct 1049 (1994). 
should have been enough to preclude us from finding on the basis of essentially the same record the exact opposite as proven beyond any genuine factual dispute for purposes of summary judgment. ${ }^{29}$

I do not seek to re-argue the case here, only to illustrate the enormous power an appellate court has to pick and choose from the record as to what the controlling "facts" of the case are. In one recent Supreme Court case, the dissent complained that "[t]he Court's account is hardly an accurate portrayal of this case." ${ }^{30}$ In a death penalty case, another dissenter lamented, "[t]he Court devotes most of its opinion to a discussion of the facts [of the crime]."31 A third dissenter recounted almost word for word six pages of a tape that was recorded at an antiabortion protest in front of a clinic, to set the tone for his First Amendment-oriented view of the dispute. ${ }^{32}$

Every judge knows the facts should carry an opinion. That is not to say that the writing judge can indulge himself in the same selective presentation of sympathetic facts (ignoring the damning ones) that counsel for each of the opposing sides does. But having made up their minds how the case will go, judges will unavoidably pick out facts and record material that impel the reader toward their conclusion of what the law should be. To be fair-most judges do try to be fair-they have to set out any cogent facts and record material that strongly support the view not taken, but they can do so in a time, place, and manner that allows them to explain why those counterfacts are not determinative. In many cases involving trial transcripts or agency records, there is more than enough evidence to sustain an outcome either way.

And sad to say, judges occasionally do fall victim to the temptation to present the facts in a skewed way, leaving out important ones, citing incomplete excerpts from testimony, conspicuously downplaying evidence going in the other direction in generalized summaries or footnotes. Although indefensible, this

23 Id at 1218 (Wald dissenting in part).

3o Thomas Jefferson University $v$ Shalala, 114 S Ct 2381, 2389 (1994) (Thomas dissenting).

${ }^{31}$ Schiro v Farley, 114 S Ct 783, 794 (1994) (Stevens dissenting). Stevens conceded that "the gruesome character of the crime is significant[,]" but went on to point out that although those facts were so favorable to prosecutors seeking the death penalty, the jury had unanimously recommended against it. Id.

${ }_{32}$ Madsen $v$ Women's Health Center, Inc., 114 S Ct 2516, 2535-37 (1994) (Scalia dissenting). 
practice is not easily discoverable to an opinion reader, unless there is a dissenter who points it out. Unlike a blatant misinterpretation of a precedent-or even a questionable interpretation of a statute - the reader cannot go to the library and read the original source. Case records are not practically available to the public; often they are not even sent to court but stored in the agency's archives far from metropolitan centers. Only the most persistent inquirer is likely to track down any suspect factual assertions in an opinion purportedly taken from the record. Moreover, the likelihood of a case being reviewed on appeal over an alleged factual misstatement in the opinion is nil. The higher the court, the more likely it sees its function as purely one of reviewing errors of law. If, then, a judge shades the record so as to support a particular result, the decision will be "review proof" unless his own colleagues take up the torch. And a dissenting judge pleading for en banc review feels she is baying at the moon when her pleas are based on the majority's failure to consider or accurately report certain facts.

This sort of purposeful misrepresentation of the record is rare, though not unknown. But judgment as to what is important, what to put in or omit from the facts section of the opinion can be colored by both the author's desire to write a persuasive opinion and his knowledge that the factual portion of the opinion is often the most critical in persuading his colleagues. Unless the law is to be perceived in Bumble's terms as "a ass," it has to follow where the facts, as retold by the judge, lead..$^{33}$

33 Charles Dickens, Oliver Twist 354 (Oxford, 1966). The presentation of the facts in appellate opinions is supposed to be based on the record alone. But often to write a comprehensible opinion, the writer has to fill in gaps, elaborate on rationales badly or incompletely explored by witnesses or lower-tier decision makers. The agency or the district court may have got it right, but done a poor job of explaining why; then, the question becomes how much beyond what the parties put in the record can the reviewing court add in order to give an adequate explanation of the holding that can be comfortably incorporated into the law of the circuit. Recourse to a standard medical text, for instance, may be necessary to make clear to the reader the difference between two conditions, each of which may cause a stroke, when the expert witness or administrative law judge botched that job on the witness stand or in the opinion below.

In theory, judges are confined to the record in front of them, but reality talks-even bites. Sometimes a judge knows from past cases, even from his own real-life experiences, that something a witness says is just plain wrong or woefully incomplete. Is he required to credit it nonetheless and carry that factual mistake over into the law, or give it full weight in the balancing as to who should win? There are outs in extreme cases: judges can say something is patently absurd or counterinstinctual or resort to "common sense" to refute it. But in arcane areas of medicine, science, or technology, common sense will not always do the trick. It is then that the judge is tempted to go to the library-since she cannot call up an expert-and try to look it up for herself. This course has evident dan- 
B. Setting the Standard of Review

Most people, if asked what judges do, would say they apply "the law" to the facts. But there is an important step in between. Appellate courts have to decide what the "standard of review" is, and that standard more often than not determines the outcome. Thus, reviewing courts will second guess the trial court on their factual findings only if they are "clearly erroneous," meaning no reasonable person could make these findings on the basis of the evidence in the record. But appellate courts can interpret the applicable law de novo; if they disagree about the law with the lower courts, they win because they are the higher-ups. Courts must defer to an agency on how a statute should be interpreted so long as the agency's view is "reasonable," and may overrule an agency's judgment only if there is not "substantial evidence" (that may be much less than a preponderance of evidence) to support it, or the agency's call is "arbitrary and capricious." Courts talk about the standard of review up front in most opinions; they announce which party has the burden of proving which facts, and what it will take to overturn the decision being appealed. Although the rules as to which standard of review applies-de novo, deference, or "clearly erroneous"-are pretty well established, there are, as with fact scenarios, different ways to describe what the standards mean as they will be applied in particular cases. A shrewd observer can usually tell the way the case will come out by the way the review standard is described (if indeed she has not already guessed from the way the facts are set forth).

Let me use a few examples from the mainstay of the D.C. Circuit-administrative law. Compare the following passages from two opinions, both written by the same judge within roughly a year of each other and describing the same standard of review for the same agency, one in which the agency prevailed, one in which it was reversed:

gers if the "fact" is actually a source of controversy in the field or experts differ on what it is. But there is equal danger in the judge passively accepting what she knows is an incomplete or wrong explanation in the record. Remand to the trial court or the agency for a more adequate explanation is sometimes an option, with a pointing out along the way why the facts already found don't suffice. But in many relatively simple cases where the judge below has gotten it right, but didn't say it exactly right, the reviewing judge will take the shortcut and fill in the gap herself. No judge wants to tell an untruthful "story," or one with a missing chapter, obvious to all. 
The courts accord a very high degree of deference to administrative adjudications by the NLRB. [The NLRB's] . . . finding is upheld unless it "has no rational basis" or is "unsupported by substantial evidence." It is not necessary that we agree that the Board reached the best outcome in order to sustain its decisions. The Board's findings of fact are "conclusive" when supported by substantial evidence on the record considered as a whole. The Supreme Court has recently instructed that a decision of an agency such as the Board is to be reversed only when the record is "so compelling that no reasonable factfinder could fail to find" to the contrary. ${ }^{34}$

and

This Court will not disturb an order of the NLRB unless, reviewing the record as a whole, it appears that the Board's factual findings are not supported by substantial evidence or that the Board acted arbitrarily or otherwise erred in applying established law to the facts at issue.... However, our review "must take into account whatever in the record fairly detracts from [the] weight" of the evidence cited by the Board to support its conclusions. We will not "merely rubber stamp NLRB decisions."

Guess which case the agency won.

Of the standard to be applied in examining an agency's change in policy, our court has written in one case:

It is axiomatic that an agency choosing to alter its regulatory course "must supply a reasoned analysis indicating that its prior policies and standards are being deliberately changed, not casually ignored." If an agency does not supply a reasoned basis for its action, the courts are not to supply one. Under basic principles of separation of powers, buttressed in no small measure by common sense, we are not to do the agency's work for it. ${ }^{36}$

${ }^{34}$ United Steelworkers of America Local Union $14534 v$ NLRB, 983 F2d 240, 244 (DC Cir 1993) (citations omitted).

${ }_{35}$ Synergy Gas Corp v NLRB, 19 F3d 649, 651 (DC Cir 1994) (alteration in original) (citation omitted).

${ }^{36}$ Action for Children's Television v FCC, 821 F2d 741, 745 (DC Cir 1987) (citations omitted). 
Yet, we have also written in another case arriving at a contrary result:

[W]e approach decisions based on an agency's interpretation of its governing statute and its regulations with all due deference. [Appellant] suggests that the court should apply heightened scrutiny to the Commission's actions under review in this case because the Commission has changed its rules and policies [under review in this case]. ... If an agency is to function effectively, however, it must have some opportunity to amend its rules and regulations in light of its experience. As this court has recently stated, "the fact that an agency rule represents a change in course simply requires courts to make sure that prior policies are being deliberately changed, not casually ignored, and that the agency has articulated permissible reasons for that change."37

- Even the familiar "arbitrary and capricious" standard may come on like a lion or a lamb:

We review decisions of the FLRA under the arbitrary and capricious standard of the Administrative Procedure Act .... [W] have recognized that negotiability and unfair labor practice determinations are "best left to the expert judgment of the FLRA in the first instance." None of this, however, relieves the FLRA of its obligation under the APA to provide a "rational explanation" of its decisions. "[T]he key to the arbitrary and capricious standard is its requirement of reasoned decision-making: we will uphold the [agency's] decision if, but only if, we can discern a reasoned path from the facts and considerations before the [agency] to the decision it has reached." ${ }^{38}$

Contrast:

Our review ... is [ ] governed by the traditional "arbitrary and capricious" standard set forth in the APA.... This review is highly deferential; we must presume the validity of agency action. The court must determine whether the agency has articulated a "rational connection between the facts

\footnotetext{
37 Florida Cellular Mobil Communications Corp v FCC, 28 F3d 191, 196 (DC Cir 1994), cert denied, 63 USLW 3687, 3689 (1995) (citations omitted).

${ }^{33}$ United States Information Agency, Voice of America $v$ Federal Labor Relations Authority, 960 F2d 165, 168-69 (DC Cir 1992) (alterations in original) (citations omitted).
} 
found and the choice made." We may reverse only if the agency's decision is not supported by substantial evidence, or the agency has made a clear error in judgment. ${ }^{39}$

This judicial tendency to transmogrify the rhetoric of review standards is not merely a cause for scholarly notice; it can have practical effects. First, there is a tendency for the "winning" and "losing" description of the same standard to become increasingly polarized over time, confusing and frustrating agencies and litigants as to what is the "real standard." More critically, once a sharp divergence in a standard is articulated, it basically does the court's work for it. Rather than going through a genuine analysis in each case, the court merely invokes the "tough" or "easy" version of the standard of review. ${ }^{40}$

\section{Controlling the Principles}

In writing opinions the court must ultimately articulate the legal "principle" or "test" by which it will make its judgment. Often the test comes from a past precedent that is simply adopted in the current opinion. But sometimes the controlling principle or test must be fashioned for the first time out of several past cases or in rare cases be improvised by the writing judge without prior precedent. Since, once announced, such a test will govern future cases, words matter. In such cases there are conscious choices to be made between tests couched in general or even abstract terms-mansions of many rooms in which implementing judges move about freely-and tests using very specific words that cabin judges' discretion tightly. "Bright line" rules accomplish the latter, "balancing tests" allow for the former. In

${ }^{39}$ Kisser v Cisneros, 14 F3d 615, 618-19 (DC Cir 1994) (citations omitted).

40 Students of the law are familiar with the controlling influence of different standards of review-the so-called three tiers of constitutional review: the rational relation test, intermediate scrutiny, and strict scrutiny. Though not absolutely challenge-proof, the tier chosen generally tells the reader whether the government wins (it usually does in a rational relation review) or loses (strict scrutiny is almost impossible to surmount). Similarly, "heightened pleading" requirements for certain kinds of civil rights claims against government officials means that the plaintiff must have all his evidence lined up before he files the suit, whereas notice pleading means he must state a plausible claim, and can rely on discovery to fill in the gaps. Needless to say, rhetoric looms large in describing and differentiating standards of review, but its role in describing what the court plans to do under the same standard in different cases is not so well recognized.

An adjunct to the standard of review description technique is a court's almost invariable citation of prior cases in which the agency won under the applicable standard if it is deciding in favor of the government and its citation only of prior cases in which the government lost, if the agency is destined to go down once more. 
proclaiming new tests and controlling principles appellate courts need also to make sure that they are clear enough for lower courts to understand. Sometimes even the subtlest differences in the words chosen or the gloss put upon them have enormous consequences. ${ }^{41}$

The Supreme Court has recently decided two cases in which the Justices rhetorically sparred over the controlling principles, one an old test, the other a newly minted one. In a much-touted "takings" case, the Chief Justice added a new constitutional requirement for the imposition by a state or city of a condition on the permitted use of a citizen's property. There, a city had insisted that an owner allow a pedestrian bicycle pathway though her property in exchange for permission to expand her store and pave her parking lot. ${ }^{42}$ The Court, following prior "takings" precedent, found "an essential nexus" between the requirement of a bike path and a legitimate state interest in easing the traffic congestion generated by the expanded store and parking facilities. But now the Court said, for the first time, the city must also show that the condition exacted was "proportional" to the impact of the newly permitted use of the property; "essential nexus" was not enough by itself. The new test was called "rough proportionality," not a "precise mathematical calculation," but still an individualized determination that the dedication is related not just in nature but also in extent to the development's impact. ${ }^{43}$ The Court rejected "reasonable relationship" as a test because it sounded too much like "rational basis," which is a frequently used test for judging state laws under the Equal Protection Clause but has come to mean only a minimal level of scrutiny by the Court; here, the Court was intent on providing a much more rigorous test, and it needed different words.

Justice Stevens, in dissent, took the rhetoric of the new test to task. He disputed "[t]he Court's assurances that its 'rough proportionality' test leaves ample room for cities to pursue the "commendable task of land use planning,", claiming that:

${ }^{41}$ See, for example, Joan Biskupic and Bill McAllister, VA Investigating Footnote to Compensation Ruling, Wash Post A2 (Jan 4, 1995) (A footnote in liberal Supreme Court ruling to compensate veterans for all VA hospital-based injuries "clouds the question of who among the 8,000 veterans with claims should be compensated.").

12 Dolan $v$ City of Tigard, 114 S Ct 2309, 2313-14 (1994).

43 Id at 2319-20.

44 Id at 2319. 
The correct inquiry should instead concentrate on whether the required nexus is present and venture beyond considerations of a condition's nature and germaneness only if the developer establishes that a concededly germane condition is so grossly disproportionate to the proposed development's adverse effects that it manifests motives other than land use regulation on the part of the city. ${ }^{45}$

Stevens continued:

The Court's rejection of the bike path condition amounts to nothing more than a play on words. Everyone agrees that the bike path "could" offset some of the increased traffic flow that the larger store will generate, but the findings do not unequivocally state that it will do so, or tell us just how many cyclists will replace motorists. . . . If the Court proposes to have the federal judiciary micromanage state decisions of this kind, it is indeed extending its welcome mat to a significant new class of litigants. Although there is no reason to believe that state courts have failed to rise to the task, property owners have surely found a new friend today. ${ }^{46}$

Thus, "two little words"-"rough proportionality"-as elaborated in the Chief Justice's opinion incorporate a tough new requirement; there must be individualized comparison of the quantitative relationship between the state-imposed condition and the impact of the owner's new use of the property. By the dissenters' light, the test imposes "a novel burden of proof" on the city and "resurrec[ts] [ ] a species of substantive due process analysis that [the Court] firmly rejected decades ago. ${ }^{347}$ Justice Souter, one of the dissenters, said that the whole case turned on the fact that the city had said only that the bike path "could" ease traffic, not that it "would." He thought such a minor difference gave no cause for the announcement of a new and controversial addition to the traditional "takings" test. ${ }^{48}$

Similarly, in NLRB $v$ Health Care \& Retirement Corp, ${ }^{49}$ the Court altered the NLRB's longstanding test for deciding who was a "supervisor," and thus not covered by the National Labor Relations Act's unionization guarantees. The Board had ruled that

\footnotetext{
45 Id at 2325 (Stevens dissenting).

46 Id at 2326.

47 Id.

48 Id at 2331 (Souter dissenting).

49114 S Ct 1778 (1994).
} 
"supervisory" activities listed in the statute, which must be exercised "in the interests of the employer," did not include nurses' supervisory activities directed at patient care, as opposed to management concerns. The Court, however, found this test created an unnatural dichotomy between the welfare of the patient and the goals of the employer and so was inconsistent with the statute. ${ }^{50}$ The dissent, which liked the old test, focused on the Act's inclusion of "professionals" and exclusion of "supervisors," arguing that only where the activities of professionals whose jobs almost always involve directing others in how to perform their duties enter into the realm of management, for example, hiring, firing, and personnel duties, do they act "in the interest of the employer." The dissent warned of "implications far beyond the nurses involved in this case," predicting ominously that as a result of the opinion "few professionals employed by organizations subject to the Act will receive its protections."

In articulating tests, judges wield power; depending on the specificity of the tests, they either encourage later and lower-tier judges to use their own judgment in weighing factors or expressing their own value preferences or seek to inhibit their discretion by tying them to tight objective indicators set out in the test. The opinions in which new tests are announced not only define the tests but elaborate on how they should be applied. The simple phrase "rough proportionality" becomes a legal requirement for a quantitative comparative assessment of the impact of the condition on the property and its benefit to the public which the government must prove. An ordinary reader might not have read all that into the phrase. When legislatures lay down statutory tests, as in the Health Care case, courts are supposed to defer in most cases to the agency's interpretation if it is at all reasonable, but as we have seen, they do not in fact always refrain from giving their own meaning to the words. "Supervisor" was surely susceptible to either the majority's or the dissent's construction in the nurses' case. It was the Court's own rhetorical description of its test that would become the determinative factor in future cases.

The description of the "test" plays a critical role in getting to the outcome. Once the test is met, burdens of proof and strict or lenient levels of review fall into place and the hurdles for the challenger can become high or low. Listen to the domino effect of

so Id at 1785 .

51 Id at 1792-93 (Ginsburg dissenting). 
a finding that a state's out-of-state waste surcharge was "discriminatory" in this Supreme Court ruling:

Because the Oregon surcharge is discriminatory, the virtually per se rule of invalidity provides the proper legal standard here, not the Pike balancing test. As a result, the surcharge must be invalidated unless respondents "can sho[w] that it advances a legitimate local purpose that cannot be adequately served by reasonable nondiscriminatory alternatives." Our cases require that justifications for discriminatory restrictions on commerce pass the "strictest scrutiny."

Needless to say, the state lost. The test is all-important in most cases, and the test is enveloped in judicial rhetoric. That rhetoric, its short- and long-term versions, sets the stage on which litigants must thereafter play.

\section{Labelling the Product}

The way in which the court describes its own holding may also be important for its future precedential status. Sometimes the court emphasizes the narrowness of what it is deciding; at other times it tells the audience that this is a broader benchmark opinion, putting other prior cases in perspective ("In this case we clarify the scope of the hearsay exception for statements against penal interest." ${ }^{35}$ ). In a split decision requiring knowledge on the part of the owner that a prohibited "firearm" has automatic firing capability so as to bring it within the statutory definition (the law was silent on the mens rea issue), Justice Thomas stressed: "We need not adopt [ ] a definitive rule of construction [as to crimes that require a mens rea element and those that do not] to decide this case .... We emphasize that our holding is a narrow one. $" 54$

Often, too, when the writer realizes that a quick look at the result is likely to arouse apprehension in the reader, she will stress what the opinion is not holding, and what its reasoning is not based on, so as to ward off a dissenter's attack and defuse anticipated criticisms. In Ratzlaf $v$ United States, ${ }^{55}$ another divided Court, in adopting a restrictive interpretation of a law

52 Oregon Waste Systems, Inc. v Department of Environmental Quality, 114 S Ct 1345, 1351 (1994) (alteration in original) (citations omitted).

53 Williamson v United States, 114 S Ct 2431, 2433 (1994).

54 Staples v United States, 114 S Ct 1793, 1804 (1994).

s5 114 S Ct 655 (1994). 
prohibiting restructuring of loan transactions to evade taxation, went out of its way repeatedly to stress what it was not doing: "[W]e do not resort to legislative history to cloud a statutory text that is clear." "We do not dishonor the venerable principle that ignorance of the law generally is no defense to a criminal charge. ${ }^{.57}$ Later courts will generally take the writer at her word and themselves stress the narrow or broad self-description of the opinion, along with its caveats as to what it is not touching.

\section{E. Parsing Precedent}

Precedent constrains not only the substance of opinions but the rhetoric as well. In some cases, it drives the rhetoric. Very few cases that reach a court of appeals' regular docket, those that are not summarily affirmed without argument or opinion, are indisputably controlled by prior cases. In most cases there are prior circuit cases or Supreme Court cases whose rulings and rhetoric are relevant, but it is still a judgment call for the court whether they require a particular outcome in the immediate case. A thorough opinion has to canvass the relevant cases, tease out the policy behind them, and either expand the reach of the precedent to include this situation or tell why it should not. This emphasis on reasoning by analogy to earlier cases is peculiar to Anglo-Saxon law. Most Continental courts interpret the text of applicable Code provisions, rely chiefly on official commentary on the Code, and do not require a court to follow its own, or even in some cases the highest court's, rulings. Ours is a system of law by gradual buildup, and the process of reasoning by reference to past cases is used to gloss statutory law as well as develop common law.

Judge-writers have distinct likes and dislikes among precedent as well as doctrines; some they would expand, some they would confine. Occasionally, where a choice is possible, judges will even select precedent according to its author because by so doing they enhance favored judges' reputations and the longevity of their output. Conversely, they may ignore or bypass precedent written by judges they disfavor, or when the occasion presents itself, downsize or discredit it, even if they cannot overrule it. Over time, precedent ignored or widely criticized loses its vitality.

5 Id at 662 .

57 Id at 663 . 
On the other hand liberal judges will sometimes purposely cite cases by notably conservative judges (and vice versa) to demonstrate the universality of the principles they are advocating. There is precedent nowadays for virtually every proposition. Judges, like patronage-givers of old, have wide choices when it comes to bestowing or denying their favors.

If the writer wishes to expand a precedent to cover the current case, she usually states the principle or policy behind the precedent in quite broad terms, cites to general "umbrella" quotes from the case, and then shows how the instant case fits comfortably within the broad sweep of that policy, citing the most persuasive facts of the present case that support the policy, and dismissing the facts that differentiate the present case from the older one as not critical to that policy. The weaker the factual similarities between the old case and the new, the more general will be the description of the principle reflected in the precedent and the quotations cited therefrom. Laudatory comments by law reviews and other courts on the principle and the precedent may be generously referenced as well.

On the other hand, when clearly relevant precedent might appear to dictate a different result from the one decided upon, it must be definitively distinguished (or, if possible, overturned). Then, the rhetoric will be dramatically different. Sometimes the precedent will be dealt with contemptuously ("ill reasoned," "rendered without explanation," "its origin overtaken by later cases," "widely criticized," "generating confusion," "at odds with other circuits," "ancient," "rarely cited or followed"). Before precedent is drummed out of the law, it must be stripped of all its decorations and merit badges. Even where the court ultimately decides it must follow the precedent, it sometimes engages in this defamation, to inform higher and future courts that it considers the precedent bad law. Often there is an explicit invitation to the Supreme Court to reconsider it because of its invidious consequences in the present case. That kind of opinion is written in a regretful tone. Translated into judicial rhetoric, it reads: "Pleas for relief must be made to a Higher Authority (or to Congress)"; "we have no alternative"; "our hands are tied"; "we only apply the law; we do not make it."

Judges who believe they have sufficient leeway to move away from a displeasing precedent follow another path. They will examine the facts and record in the precedent and the instant case minutely to unveil critical differences between them. They will then proceed to explain-often at length-why these differences 
are more important than the similarities, and why applying the precedential policy in light of these fact disparities would provoke disastrous and clearly unintended consequences for the parties and the policy. In such opinions the precedents are discussed in terms of what they did not say rather than what they did say, further to stress their nonapplicability to the present case.

Needless to say, these exercises in judicial distinction sometimes invoke cynicism among dissenters and commentators, but so do many cases in which the reach of precedent is expanded. Judges' latitude to follow or distinguish earlier cases is particularly wide where the original precedent is stated in terms of a number of factors peculiar to that case. Successive cases can then either call each factor critical or noncritical according to whether it is present or absent in the new case. One recent illustration of this phenomenon has occurred in the drug testing arena.

In National Treasury Employees Union $v$ Von Raab, ${ }^{58}$ the Supreme Court recognized that a government-compelled urinalysis constitutes a "search" subject to the restrictions of the Fourth Amendment, but found that certain circumstances could nonetheless justify mandatory testing even in the absence of individualized suspicion. "[W] special governmental needs, beyond the normal need for law enforcement," the Von Raab Court wrote, "it is necessary to balance the individual's privacy expectations against the Government's interests...." ${ }^{n 9}$ In striking this balance, the Court recognized three government interests: protecting the safety of the public from dangers posed by armed Customs officers; protecting the integrity of frontline drug interdiction personnel; and protecting truly sensitive information. ${ }^{60}$ The Court also enumerated factors that it deemed relevant to the intrusiveness of a testing program, including: whether employees receive advance notice of a test; whether the jobs involve day-to-day contacts with coworkers in the office environment that might provide an alternative means of detecting serious drug problems; whether testing is limited to applicants for promotions or applied to employees' present jobs as well; and whether the government makes an effort to limit access to truly sensitive information so as to cut

\footnotetext{
63 489 US 656 (1989).

cs Id at 665-66.

is Id at 668-70.
} 
down on unnecessary searches. ${ }^{61}$ No "aggravating" factors of these sorts were present in Von Raab.

Von Raab did not, however, establish which (if any) of the government interests enumerated would be essential to a constitutional testing program, nor which (if any) of the "intrusiveness" factors would suffice to invalidate such a plan. That task was left to the lower courts. The D.C. Circuit's cases following Von Raab have steadily moved toward the curious position that none of the government's interests enumerated by the Supreme Court need be present to uphold a testing program, while no combination of relevant factors indicating a heightened invasion of privacy will render such a plan invalid.

Harmon $v$ Thornburgh ${ }^{62}$ the first D.C. Circuit case interpreting Von Raab, involved a random urinalysis drug testing program covering three categories of Department of Justice employees: prosecutors in criminal cases; employees with access to grand jury proceedings; and personnel holding top-secret national security clearances. The court found that the "public safety" and "integrity" rationales of Von Raab had no application, and that only those employees with top security clearances had access to "truly sensitive" information. It therefore invalidated the program as applied to employees in the first two categories. ${ }^{63}$ With respect to individuals with top security clearances, however, the court dismissed the employees' arguments that the testing was unnecessarily intrusive because of the proposed random selection method, because testing applied to all employment (not just promotions), and because testing was not necessary in the "office environment" of the DOJ where drug abuse would be revealed through day-to-day contacts. The court found that these factors, while "relevant," were insufficient to invalidate the program. ${ }^{64}$

A second case, American Federation of Government Employees $v$ Skinner, ${ }^{65}$ involved Department of Transportation mail van operators with "secret" or "top-secret" security clearances. The court held that "secret" information was, like the "top-secret" material in Harmon, "truly sensitive" within the meaning of Von Raab. The court found "significant" the fact that the covered

\footnotetext{
61 Id at $672-74 \& \mathrm{n} 2$.

62878 F2d 484 (DC Cir 1989).

63 Id at $490-92$.

64 Id at 492 .

65885 F2d 884 (DC Cir 1989).
} 
employees worked in settings "other than the "more traditional office environments," and upheld the testing program. ${ }^{66}$

Hartness $v$ Bush ${ }^{67}$ also involved individuals with "secret" clearances, this time in the Executive Office of the President, a traditional "office environment." The court nonetheless established a per se rule that individuals who hold a "secret" national security clearance may be subjected to random urinalysis, abandoning its earlier emphasis on the absence of supervision in a nontraditional work environment. ${ }^{68}$

Finally, in National Treasury Employees Union $v$ United States Customs Service, ${ }^{69}$ the D.C. Circuit addressed the Customs Service's plan to test all employees with access to certain computer databases. The employees did not have secret or top secret security clearances. They worked in traditional office environments. The tests applied to incumbent job holders as well as to job applicants. The tests were random and performed without notice. The Customs Service provided no evidence that it had attempted to restrict the user pool to minimize the number of intrusive searches performed. Nonetheless, the court upheld the program on the ground that employees' access to "sensitive" information in the databases could compromise the Customs Service's drug interdiction efforts. ${ }^{70}$

My hunch is that the bulk of the rhetoric of appellate opinions is spent in explaining why past cases do or do not apply. In some cases, however, there simply is no precedent. Cases involving statutory interpretation are more apt to be ones of first impression. The debate here is whether the so-called "plain language" of the law will prevail and the court will look at text only (sometimes supplemented by judicial gloss on text) or go behind the text to consult congressional hearings, committee reports, and floor debate to find Congress's intent. Both sides of the "textualist" debate have strong proponents. It is usually easy to tell after the first paragraph of an opinion which road the court will go down, by the quotations they lead with. Eminent spokesmen abound for both sides-Oliver Wendell Holmes, Felix Frankfurter, and Learned Hand have all proclaimed the folly of construing words outside of context. Antonin Scalia, Clarence Thom-

\footnotetext{
s Id at 892-93.

67 919 F2d 170 (DC Cir 1990).

$\leftrightarrow$ Id at $172-74$.

69 27 F3d 623 (DC Cir 1994).

${ }^{70}$ Id at 627,630 .
} 
as, and Alex Kozinski regale us with the unreliability of legislative history written largely by aides and lobbyists. There are code words by which to predict whether plain meaning or legislative history will win the day in a particular case. Reference to "absurd" results means "plain language" will not rule. References to the Supreme Court's Chevron ${ }^{71}$ decision, instructing courts that they must defer to an agency's interpretation unless it is clearly unreasonable or contradicts express statutory intent, harbingers ill for the challenger. Any one of a number of vintage quotes about language being susceptible of many meanings is a sure sign the court will look further at nontextual materials. The plain language-legislative history dispute has been with us now for a decade; the battle lines are clearly drawn, and a judge-author entering the battlefield has generally chosen his strategy early on. ${ }^{2}$

There are also a few cases not involving statutory interpretation where no precedent is even arguably on point. The absence of precedent is liberating to a writing judge. The court can decide

7 Chevron U.S.A. Inc. v Natural Resources Defense Council, Inc., 467 US 837 (1984).

72 A triumph for the "plain meaning" textual, dictionary school of jurisprudence came in National Organization for Women, Inc. $v$ Scheidler, 114 S Ct 798 (1994), which decided that RICO applied to "enterprises" engaging in "racketeering activities" whether or not the underlying motive was economic. "Nowhere in either $\$ 1962$ (c), or in the RICO definitions in $\S 1961$, is there any indication that an economic motive is required." Id at 804 . As to one relevant definition which included activities that "affect" commerce, Webster's Third International Dictionary was duly consulted with the observation that "affects" encompasses activities that may influence commerce, but need not themselves involve commerce. The pieces of legislative history about congressional intent were sidestepped in a conclusory manner:

We [ ] think that the quoted statement of congressional findings is a rather thin reed upon which to base a requirement of economic motive neither expressed nor, we think, fairly implied in the operative sections of the Act. $\cdots$

Both parties rely on legislative history to support their positions. We believe the statutory language is unambiguous and find in the parties' submissions respecting legislative history no such "clearly expressed legislative intent to the contrary" that would warrant a different construction.

Id at 805-06.

But perhaps the high point in the dictionary school of jurisprudence came in $M C I$ Telecommunications Corp v American Telephone \& Telegraph Co., $114 \mathrm{~S} \mathrm{Ct} 2223$ (1994), where the dispute degenerated to one involving which edition of which dictionary prevailed as to the meaning of "modify." This semantic quibble was the linchpin in an important case involving the power of the Federal Communications Commission to permit some companies not to file public tariffs. The dissent, which would have upheld the Commission, used its own adjectival rhetoric to chastise the majority for denying legitimate authority to the FCC, calling the FCC's decision "eminently sound, experience-tested, and uncommonly well explained." Id at 2239 (Stevens dissenting). 
on equity or policy grounds how the case should come out, giving due weight to what its outcome will mean in future cases. These are the most interesting cases for judges, and ones in which their views of the world are most likely to march onto the pages. They are usually the most interesting cases to read as well, since the author drops the "how constrained I am" mode and must set down with candor the hierarchy by which she rates the benefits and burdens of different outcomes. The basic analytical structure that judges use to decide such cases-be it risk assessment, utilitarian weighing of costs, or political philosophy-not only determines the results but displays the judge's own inner thought processes. The rhetoric will generally follow that of the analytical mode chosen, and the adoption of a particular way of analyzing the problem may be as important to the judge as the instant result.

These "founding parent" cases prove most influential in the development of the law, for they lay down a decisional structure for future cases to follow. Their rhetoric will sound very neutral and principle oriented, as if the results in this or any one case were secondary. The authors, however, are quite aware that they are determining or influencing the outcome of many cases, defining a field of law and the considerations or values that will predominate. These "rule" opinions, incidentally, are not always confined to first impression cases. Sometimes a court will undertake to synthesize past decisions or coalesce its "fundamental principles" in the course of the new opinion. The court will look at a series of prior cases and, instead of distinguishing some and finding common themes in others, place all or some of them into a new context which then becomes the formal rule in future cases. In the course of the exercise some old rulings may be discarded as out of conformity with the new "rule." The rhetoric in these brush-clearing cases will usually stress the confusion and inconsistency among prior cases, the need for clear bright lines for enforcement personnel or for private transactions, and the ability of the new rule to bring about the right result in most-if not all-cases.

A sampling of Supreme Court rulings in the past few terms reveals the different rhetorical styles that accompany different treatments of precedent. Let's start with the "over and out," "there's no real question here" opinion that aggressively cites precedent as controlling on its face and the lower court's inability

${ }^{23}$ See United States v Bailey, 36 F3d 106, 118 (DC Cir 1994) (en banc). 
to follow the precedent as inexplicable. The opening phrases or a few core sentences tell the opinion's "story."

Our decisions make clear that ... Berkemer ... reaffirmed the conclusions reached in Beckwith.... It is well settled, then, that...[t]he California Supreme Court's analysis ... is not consistent in all respects with the foregoing principles. ... So understood, the court's analysis conflicts with our precedents. ... Our cases make [this] clear, in no uncertain terms....W therefore reverse its judgment.... . ${ }^{74}$

Compare the rhetoric in a different kind of case in which the Court must surmount its own inconsistent former rhetoric:

Respondent appeals to our statement . . . in Julian $v$ Central Trust Co. . . . The doctrine of ancillary jurisdiction ... does not stretch so far as that statement suggests. The expansive language of Julian can be countered by (equally inaccurate) dicta in later cases that provide an excessively limited description of the doctrine. The holding of Julian was not remotely as permissive as its language. ... It is to the holdings of our cases, rather than their dicta, that we must attend, and we find none of them that has ... relied upon a relationship so tenuous [as is involved here]. Generally speaking, we have asserted ancillary jurisdiction . . . for two separate, though sometimes related, purposes .... Neither ... supports the present assertion of jurisdiction. ${ }^{75}$

The technique here, of course, is to label the troubling statement dicta, cite to different dicta on the other side of the issue, emphasize the different facts of former cases and classify the holdings of those cases as embodying certain underlying principles, none of which is advanced by holding similarly in this case.

And finally, compare the rhetoric of a decision in which the Court overturned a prior precedent. ${ }^{76}$ Following the cardinal rule that "Those Precedents Which the Gods Would Destroy, They First Belittle," the Court marched pejoratively through to annihilate its earlier holding. It referred to the "fractured deci-

${ }^{74}$ Stansbury v California, 114 S Ct 1526, 1529-31 (1994) (per curiam).

75 Kokkonen $v$ Guardian Life Insurance Co. of America, 114 S Ct 1673, 1676 (1994) (citations omitted).

${ }^{78}$ Nichols v United States, 114 S Ct 1921 (1994). 
sion in Baldasar,"77 and to "the issue that splintered the court in Baldasar." ${ }^{\text {"8 }}$ It lamented that Baldasar provided no rationale for the result. It identified the dissenting judge in Baldasar as the revered, now retired Justice Powell and discussed the basis for his dissent at length, noting, "[Q]uite presciently-the dissent predicted that the Court's decision would create confusion in the lower courts." Anticlimactically the Court concluded, "Today we . . overrule Baldasar.

Whether precedent should be overruled outright often divides the Court. In the 1993-94 term, a voting rights case, Holder $v$ Hall, ${ }^{81}$ decided that a challenge under $\S 2$ of the Voting Rights Act for dilution of voting rights could not be levied on the basis of a change in the size of a governing authority. Although the dissenters thought this result "inconsistent with our precedent," a concurring opinion of nearly sixty pages (the majority opinion was only six) filed by Justices Thomas and Scalia argued for a reinterpretation of $\S 2$ that would expressly wipe out an entire line of precedent on the ground that the Court had taken a wrong turn many cases ago and was going farther and farther into a dark wood. Justice Stevens wrote specially to refute the Thomas position:

When a statute has been authoritatively, repeatedly, and consistently construed for more than a quarter century ... judges have an especially clear obligation to obey settled law. Whether Justice Thomas is correct that the Court's settled construction of the Voting Rights Act has been "a disastrous misadventure," ... should not affect the decision in this case. It is therefore inappropriate for me to comment on the portions of his opinion that are best described as an argument that the statute be repealed or amended in important respects. ${ }^{82}$

Judges who resist overruling precedent often rely, as Justice Stevens did, on the constitutionally based duet between Congress and the courts: the courts construe statutes, and Congress in deciding to keep those statutes on the books accepts that they mean what the courts say they mean. Thus it would be in effect a

\footnotetext{
77 Id at 1925.

78 Id at 1924.

79 Id at 1926.

so Id at 1928.

81 114 S Ct 2581, 2591 (1994).

${ }_{62}$ Id at 2629-30 (Stevens separate opinion).
} 
breach of trust to change interpretations midstream. Judges, like Justice Thomas, who urge dramatic change, warn of applying stare decisis "mechanically" when the results are disastrous ("federal courts are engaged in methodically carving the country into racially designated electoral districts") and attributable to earlier misconstructions by the court. No question that veering from past precedent is convulsive for a divided court, but it is still fascinating to see how easily the rhetoric can smooth it over when a secure majority is firm in its conviction that it must be done.

\section{F. Defending Dicta}

Some copious opinions contain not only facts, background, and discussions of relevant law, but excursions into the implications of a decision one way or the other, predictions on the nature and course of future cases, and even personal observations of the author. Law school teachers and commentators revel in this kind of opinion; it provides excellent fodder for classroom and law review feedings. Judges are of mixed mind. We do not view opinions and law reviews as functional equivalents, and the more "extras" an opinion contains, the more there is to take issue with and explain away in future opinions. Many judges prefer their opinions lean and tight and denigrate the more discursive opinions of colleagues as exercises in "show and tell." The opinions of veteran judges, whether from wisdom or fatigue, do tend to be shorter.

Deciding how much nonessential material to put in an opinion is a judgment call, but one that reflects a variety of motives. If the case involves a highly technical subject, it may be necessary to explain terms and processes to make the issue, let alone the result, comprehensible. (We now attach glossaries to our more complex D.C. Circuit agency review opinions.) The discipline of explaining in ordinary language what is involved in the dispute often highlights for the writing judge heretofore hidden problems or uncovers areas of ignorance or confusion that she may have glossed over in reading the briefs or listening to the argument. Similarly, in statutory interpretation cases a disputed phrase or section of a statute often has to be put in its full context to make any sense; the structure, purposes, and history of the entire statute may have to be examined.

Sometimes, too, when the opinion is breaking new ground or applying old doctrines to new situations, the evolution of the doctrine needs to be outlined and explicated to persuade the audience that it should be extended. In an important cable TV- 
First Amendment case, Justice Kennedy spent the first seven pages of his opinion recounting the regulatory history of cable TV in the United States. ${ }^{83}$ If the legal landscape is strewn with arguably inconsistent precedent, it must be sorted out. If the court or the author herself has said inconsistent things in past opinions, they must be distinguished or even repudiated. (The mea culpa or crow-eating opinion is a familiar genre to most judges who sit long enough. ${ }^{84}$ ) Sometimes, too, a judge will use a case, not of major significance in itself, as a vehicle to expound on a larger social, political, or legal issue. This practice, in turn, may give rise to accusations of "judicial legislation" or "judicial activism." Yet most judges think it justifiable to use a particular case to document the existence of a wider practice on the part of law enforcement or agency officials that the court thinks is illegal, unethical, or at least problematic and to send a signal that it will not be tolerated. Thus, we frequently excoriate police practices that result in destruction of Jencks Act materials, incomplete warnings by police before conducting citizen searches, and "nonacquiescence" policies by agencies in the court's rulings. These "lecturing" opinions implement the court's function as an occasional overseer of aspects of the administration of justice outside the courtroom that affect justice inside the courtroom. The court has a unique vantage point from which to spot questionable practices that show up in a number of separate cases. While technically these "lectures" are dicta, most would consider them legitimate to the extent they are confined to practices that affect the judicial records that come before the court. Commentaries on broader political and social policies that give rise to problems such as drug use, homelessness, or welfare dependency are more debatable.

Signals to other branches of government that the court thinks they should conduct their business in a certain way are generally considered out of order, so long as what they do is within the law. There are exceptions. Signals to Congress can be appropriate where the court, after a difficult analysis of what a law means, suggests it might clarify its intent by amending the law. In fact, the D.C. Circuit has for several years forwarded opinions in which such suggestions are made to designated recip-

* Turner Broadcasting System, Inc. v FCC, 114 S Ct 2445 (1994).

\& See Henslee $v$ Union Planters Nat'l Bank \& Trust Co., 335 US 595, 600 (1949) (Frankfurter dissenting) ("Wisdom too often never comes, and so one ought not to reject it merely because it comes late."). 
ients in Congress for distribution to the relevant legislative oversight committees. In the same vein, our court has pleaded with the Sentencing Commission to "reconsider and rewrite its application notes [to the Federal Sentencing Guidelines] so that they are intelligible to all circuits. ${ }^{285}$

More dubious examples are where the court, in reviewing an agency's rationale, decides it is not well reasoned enough to pass muster and then suggests a specific one that would survive scrutiny. Often an intimidated agency will take the hint and adopt the suggestion. The court's role is only to decide whether the agency's interpretation is reasonable, not which of a number of reasonable alternatives it should choose. These kinds of policychoice-oriented dicta not only risk overstepping the court's proper role but additionally can mousetrap an agency that adopts them and then comes for review before a newly constituted panel that disagrees with the dicta in the prior opinion.

Still, one judge's dicta may be another judge's coherent rationale. In a sense, everything in an opinion that does not strictly involve the application of a legal principle to the critical facts is dicta, but few would advise that all opinions should stop at that point. Dicta have useful purposes, but they also have mischievous potential to cloud the essence of the holding, to promise things in future cases they cannot deliver, to pressure officials in other branches they cannot control, to overexplain the writer to the reader.

Some judges decry dicta in principle; others defend them on the ground that the reader-judge or citizen is benefitted by a full look at all the considerations that have gone into the decision, even the dead-end side trips. Dicta may be necessary if the author wants to be candid in revealing that it is a close case and he still has some doubts about which way to go, or about the consequences of the way he has chosen. From an educational point of view, discussing rejected theories, speculating on consequences, probing doubts, can be of assistance to peer courts considering the same issue; they can also inform a reviewing court and aid litigators by showing which arguments troubled the court most. Lawyers like to think they have been listened to even when they lose, not treated as though they were foolish or misguided in bringing the case to court in the first place. The same candor can, however, create confusion as to how solid the holding is, how long it is likely to last, whether it is vulnerable to en banc or Supreme

${ }^{85}$ United States v Montague, 40 F3d 1251, 1256 (DC Cir 1994). 
Court review, or even congressional overthrow. Short, cryptic, Holmes-like statements of what the result must be, backed by an authoritative-sounding assemblage of cases or texts is, in the eyes of many, a more judicially appropriate mode than "letting it all hang out." Court scanners like to speculate that the judge's "real reasons" are often in the dicta, not in the holding itself, and sometimes they may be right. As a matter of pure craftsmanship, however, the core ruling of an opinion can be obscured or buried in too much talk, not keyed directly into the holding. But line drawing between holding and dicta can be blurry; as we have seen, the same language of a prior opinion is often classified differently by future judges dependent on whether they like what it says or not. Dicta, of course, are often an essential part of the author's storytelling effort-in the facts, to elicit sympathy or outrage; in the explanation of precedent, to suggest why it should or should not apply; in the prediction of disaster or the call to arms, to stand firm against an argument or interpretation advanced by one side. It is probably fair to say that few talented writers would be drawn to the bench if they could not indulge in dicta when writing their opinions; without it the "story" would be no more than a synopsis.

A subset of the dicta debate is how far an appellate opinion should go in laying down detailed rules for adherence to its holding. Is the judicial rule more properly confined to saying "yes" or "no" to the legality of the particular challenged actions before the judge, leaving the multitudinous other official responses to the underlying problem for future cases? Some see such a limitation as a necessary component of judicial restraint. The Supreme Court's path in the abortion controversy is a much-debated example: should the Court have just said "no" in the beginning to the particular state statutes it believed crossed the line, as opposed to what it actually did in Roe $v$ Wade $e^{86}$ by setting out a constitutional scheme to which all states had to adhere? Ultimately, of course, the Court ended up making a series of midcourse corrections in its original approach. ${ }^{87}$

The Court took a different tack in death penalty cases, proceeding to lay out its jurisprudence on a case-by-case basis, and in the school segregation cases it adopted that phrase of many meanings, "with all deliberate speed," leaving the implementation of state school desegregation to be negotiated site by site

\footnotetext{
410 US 113 (1973).

s7 Planned Parenthood of Southeastern Pennsylvania v Casey, 112 S Ct 2791 (1992).
} 
between local school boards and federal district judges. On the one hand there are ever increasing demands for more bright lines to help law enforcement and other executive officials know what will pass muster in court and to impose consistency throughout our far-flung judicial system; the so-called Miranda Rule reciting almost verbatim what a policeman must say before questioning a suspect was motivated by the search for such certainty. On the other, there is persistent rumbling about courts acting like legislators and laying down broad rules of behavior rather than deciding if the officials acted legally or illegally in a particular case. Courts tend to be caught in the middle, once again struggling to uphold both legal consistency and judicial legitimacy.

\section{G. The Separate Voice}

Judges write in a different voice when they concur or dissent. They speak on their own rather than for the court. Why and when do judges write separately? The question is easiest to answer in the case of a dissenting judge. She is driven publicly to distance herself from her colleagues out of profound disagreement, frustration, even outrage. A dissenter is admitting she has not been able to convince her colleagues, and because she herself cannot be convinced by their logic, she can be seen as implicitly criticizing them for being obtuse, lazy, bullheaded or some variation on those qualities-before she ever writes a word. Most judges dissent reluctantly. A dissent makes no new law; it highlights -one's difference from a majority of colleagues, and it means extra, self-assigned work. Some judges in careers of many decades write only a smattering of dissents; others write a dozen or more a year. A judge's temperament-the inveterate loner, rebel, nonconformist, or the conciliator, the tagger-along, the believer that it is "more important the result be unanimous than be right"-often shows up in his dissent record. A dissent speaks to the rest of the court, to courts in other places, to higher courts, to Congress, to future generations; it brings no hope of present reward or vindication.

The typical tone of a dissent is troubled, outraged, sorrowful, puzzled. It is most apt to turn away from the technicalities of the majority holding and play to higher levels of aspirations and values that it sees desecrated by the majority's insistence on a relentless imposition of precedent regardless of the consequences. Usually it is accompanied by a parade of horribles or warnings of the slippery slope down which the majority is sliding. Far more than in majority opinions, the voice of a single dissenting judge 
uses the first person to speculate, make dire predictions, or chastise colleagues who have gone wrong. Although it has traditionally been the custom to end with "I respectfully dissent," occasionally the writer is so upset that she drops the "respectfully." The irate dissenter is apt to begin with some variation on the theme, "Never in my ten years on the bench have I seen a case as sad as this." The strategy of personalization in dissent is to separate the dissenter from the cold, impersonal, authoritarian judges of the majority, who impliedly do not take the human condition into account when they mercilessly impose "the law."

A dissent is liberating. No other judge need agree or even be consulted. Exuberant (or excess) prose is unconstrained. Famous jurists such as Brandeis, Holmes, Black, Douglas, Frank, Wyzanski, Bazelon, and Wright, are probably better known for their dissents than for their majority opinions. But dissents can be dangerous if not disciplined. They weaken the court's authority; they can turn both opinions into high school debating exercises full of "thrust and parry" footnotes; they mark the author as out of the loop; they can leave lasting scars on colleagues. If the case is newsworthy, the dissent will inevitably be characterized as "biting," "scathing," "powerful," "strong," or "acerbic," resulting in a "divided," "fractured," or "split open" court. It is, of course, possible to write a calm, moderate, restrained dissent, but the question arises: if the difference between the majority and dissent is so mild, why write at all? Logically, a dissent can usefully point out better alternatives to the majority's result or reasoning, or dangers in the development of the law which, while not earth shaking, are nonetheless worth noting. In the main, such workmanlike dissents do not, however, excite or incite changes in judicial thinking. A sense of urgency and of impending doom is almost a sine qua non of the dissenting voice.

Concurrences are a different matter. Judges write concurrences for more subtle reasons than dissents. Though certainly not as threatening as dissents, concurrences raise more collegial eyebrows, for in writing separately on a matter where the judge thinks the majority got the result right, she may be thought to be self-indulgent, single-minded, even childish in her insistence that everything be done her way. Most judges dissent more than concur, on the theory that only a real and deep difference in how the law should go justifies pushing oneself front and center stage to say one's piece. Yet concurrences are not that infrequent and may be motivated by a variety of factors. One such factor is assuring the losers (and their supporters) that the result is not so 
horrendous as it might seem. For instance, Justice O'Connor, concurring in the Kiryas Joel case, ${ }^{88}$ set out suggestions for how the special educational needs of the Orthodox Hassidic sect might be accommodated in a constitutional manner, although she agreed with the majority that the manner the state had actually chosen was unconstitutional. A second motive is taking issue with the majority's rationale. In the same concurrence, Justice O'Connor wrote her thoughts on the efficacy of the much-debated Lemon test for deciding church and state issues as well as her preference for "recogniz[ing] the relevant concerns in each case ..., rather than trying to squeeze them into language that does not really apply to them" by laying down "a Grand Unitary Theory." ${ }^{189}$ A third reason is to put forth reasons supporting the result the majority did not see fit to offer, or at least offer prominently enough. Justice Stevens, concurring in one case recently, endorsed the "thorough analysis" of the majority but wanted to add a "comment for emphasis." $\mathrm{A}$ fourth is to warn that additional concerns in future cases may bring about different results. Justice Souter, agreeing with the application of RICO to noneconomically motivated "enterprises," was nonetheless concerned about First Amendment problems that might be involved in this and future cases:

I express no view on the possibility of a First Amendment claim by the respondents in this case [that was not within the question accepted for certiorari]. But I think it prudent to notice that RICO actions could deter protected advocacy and to caution courts applying RICO to bear in mind the First Amendment interests that could be at stake. ${ }^{91}$

And finally, judges concur to underscore their own limited interpretation of the majority opinion as a precaution against too broad a future interpretation. Witness Justice Scalia's recent concurrence: "I join the Court's opinion, which I do not understand to require the simplistic view of statements against penal

83 Board of Education of Kiryas Joel Village School District v Grumet, 114 S Ct 2481, 2498 (1994) (O'Connor concurring in part and concurring in the judgment).

89 Id at 2498-99.

90 PUD No. 1 of Jefferson County $v$ Washington Department of Ecology, $114 \mathrm{~S} \mathrm{Ct}$ 1900, 1914-15 (1994) (Stevens concurring).

91 National Organization for Women, Inc. $v$ Scheidler, 114 S Ct 798, 807 (1994) (Souter concurring). 
interest that Justice Kennedy [another concurrer] attributes to it." ${ }^{.92}$

Concurrences are always dicta, pure and simple. They serve as vehicles for judges to present additional arguments rejected or ignored by the majority, to preserve doubts or reservations about the majority opinion for the future, to caution against its toobroad application, to disagree with all or part of its reasoning. The tone of concurrences is usually calm and rational, not agitated as in a dissent-after all, their authors agree with the result. Concurrences seek only to bolster the rationality and contribute to the viability of the majority's holding-the authors say. In the writing, however, the authors keep a careful eye on their own judicial identities to assure they remain intact for future battles, yet unseen.

\section{STyle AND Personality}

Judges, like other writers, never succeed altogether in hiding their own personalities behind the black robes. Tightly contained, retentive personalties write abbreviated "facts and law" opinions almost daring the reader to go behind the formal facade; expansive personalities are all too eager to share their thought processes. My first boss, Jerome Frank of the Second Circuit, was certainly the latter, given to excursions into other disciplines for insight on legal problems and the sharing of odd and interesting tidbits of information along with spur-of-the-moment witticisms and literary allusions. One story-perhaps apocryphal, perhaps not-is that one clerk to whom he had given a long discursive draft of thirty pages or so for critiquing handed back, somewhat tentatively, a crisp five-page version containing all the necessary facts and law, and then waited apprehensively for Frank's reaction. "Splendid," the good judge said, "I've tacked it on at the end of the opinion as a conclusion." Like Hemingway, other judges write to the bone, abhorring descriptive adjectives; still others delight in injecting exotic language in their opinions, calculated to send readers, including other judges, scurrying to the dictionary. We write what we are, and perhaps, more than others, judges are what they write.

Yet there are exceptions. Sometimes a judge purposely "writes down" to defuse a volatile subject. A few years ago I wrote an opinion during the latter days of the Bush administra-

$\$ 2$ Williamson v United States, 114 S Ct 2431, 2438 (1994) (Scalia concurring). 
tion holding that a White House attempt to modify the "gag rule" against federally funded prenatal health clinics providing information or advice on abortion was procedurally flawed; the original "gag rule" had been adopted by notice and comment as a regulation, and any amendments to it must be similarly effectuated. ${ }^{93}$ The opinion was written in the same matter-of-fact style as if it were talking about ball bearings or emission standards. The subject matter was downplayed to emphasize that ordinary garden-variety administrative law standards were at issue, nothing more, and the same procedural requirements applied to abortion-related matter as to any other subject of agency regulation. That technique, of course, does not always succeed; in my case it did not. Predictably the press played the opinion as a pro-choice overthrow of the antiabortion "gag rule," although there was not a substantive word about the merits of abortion in it.

Over time judges adopt special writing styles. Justice Scalia uses conceptual phrases sarcastically, always set out in capital letters. He peppers his opinion with caustic references to the "Powers That Be" and the "Land of the Free." An example: "[I]n the Land of the Free, democratically adopted laws are not so easily impeached by unelected judges. ${ }^{.94}$ One judge on our court used italics so much that he was referred to as the "Neon Lights" judge. Some judges interject their own personal views and experiences into opinions. In a recent dissent, Judge Sentelle admitted it was "perhaps a cardinal sin for an appellate judge... [to] recall [his] own experience in the trial courts," and "[f]or a dissent to express [ ] sweeping pronouncements [that] would be less than dicta," but then went on for six pages to "yield to the temptation of expressing some rudimentary thoughts on [the] subject. ${ }^{295}$ Occasionally, judges make plays on words, or engage in double entendres, or sprinkle movie titles throughout their opinions, a game of hide-and-seek for the playful reader. But for the most part such exercises are aberrational-writing opinions is a "damnable serious business," and litigants are not likely to enjoy jokes made at their expense. ${ }^{96}$

93 National Family Planning and Reproductive Health Ass'n, Inc. v Sullivan, 979 F2d 227, 241 (DC Cir 1992).

${ }_{94}$ Board of Education of Kiryas Joel Village School District $v$ Grumet, 114 S Ct 2481, 2508 (1994) (Scalia dissenting).

${ }_{95}$ United States $v$ Smith, 27 F3d 649, 665 (DC Cir 1994) (Sentelle dissenting).

${ }_{96}$ See, for example, Note, Judicial Humor: A Laughing Matter?, 41 Hastings L J 175 (1989) (analyzing public and legal reactions to judicial humor); Richard Delgado and Jean Stefancic, Scorn, 35 Wm \& Mary L Rev 1061 (1994) (advancing thesis that Supreme Court 
There is, however, one substantial recent development in judicial style. That is the trend toward "natural language" in judicial opinions as opposed to hypertechnical legalistic prose. This is healthy, I think, not only as a matter of style and accessibility, but because it helps avoid pitfalls in judicial thinking. The older style was to express everything in formal legal terms encompassing fairly rigid categories or legal concepts and then to let those categories do all the work of deciding the case. So, for example, judges would ask, "Is this a right or a privilege?" and if it was characterized as a right plaintiff won, and if it was a privilege plaintiff lost. No need for complex analysis; just characterize, categorize, then mechanically apply the rule. Natural language loosens this up a bit; decision making becomes less rigid, more fluid and context sensitive; judges using it need to say a bit more about why the case is like (or unlike) previous ones, and there is more room for both parties and judges to maneuver.

At its core, however, judicial decision making still fundamentally and inescapably involves a process of categorization and application of rules and analyses based on the category chosen ("Is this a First Amendment case, or not? Is there state action, or not? Is this protected speech, or not? Is this a public forum, or not?"). What natural language does is to make the legal categories somewhat more open textured and less rigid, and expand the range of judicial discretion to characterize both facts and law. It also makes the exercise of judicial discretion somewhat more obvious, so that while judges still typically write as if they were absolutely certain about the rightness and soundness of their analysis and decisions, everyone (including the judges) knows that's not necessarily the case. Consequently, I think judges are less likely to fall into the trap of believing they are merely the vessel through which some deus ex machina ineluctable version of legal truth reveals itself; they need to do more analysis, be more sensitive to context, sift the facts more carefully, and think about why this case is really like (or unlike) another. That, it seems to me, is a worthy development.

A side product of the new "natural" writing style is the more frequent use of catch phrases associated with ordinary life experiences that judges attach to systemic legal issues or doctrines. One opinion characterized the argument that police officers must seek specific consent to open each of a suspect's enclosed bags or containers despite the suspect's general consent to a search of his 
luggage as the "Mother-May-I" theory, after the name of a childhood game. ${ }^{97}$ Cases involving the search of a suspect's crotch area for drugs ${ }^{98}$ are referred to as the "groin grope" cases, graphically summing up what is practically at stake. But the popular name given to a rule can conjure up a powerful reaction, which can be just as dangerous to rational analysis as legal jargon. I have always thought the FCC gained a huge psychological benefit when it labelled its rules for banning certain programming it found offensive to community standards the "Indecency Rules." After all, who could be for indecency on the airwaves?

A final point on style: Judges traditionally write opinions in an impersonal tone. "The court this" or "the court that"-the imperial "we." The impersonal style was designed to advance the notion that the court is a corporate body involved in declaring what the law is rather than three or nine or twelve individuals. Historically, to interject the personal "I" or "me" or to recount any impression or experience of the opinion writer was seen as a break in that facade, a signal to the reader that there might be a fallible figure behind the Wizard's voice. Of late, however, it is not so unusual to see judges speaking in the first person, setting forth bits of their own experience or views-more frequently in the trial courts than above, and more in dissents than in majority opinions. It suggests the mortality of the writer, the fact that she is one human being bringing to bear on the problem her talents, views, and experiences rather than handing down a commandment received on high; I see that too as a promising breakthrough. Some feminists would encourage more "storytelling" in opinions; some judges have already broken the mold and write in a folksy way, interspersing the facts and legal analysis with homespun observations. By bringing the author down nearer to the human level of the litigants, such techniques force her to think about the human facets of the case, the "beyond the law" aspects, and perhaps to factor them into an ultimate conclusion that must then make sense in ordinary human terms, not just "the law says so." In the end, this humanization of the judicial process can only help to bolster the legitimacy of our courts-or so we hope.

97 United States $v$ Battista, 876 F2d 201, 207 (DC Cir 1989).

${ }^{93}$ See, for example, United States v Rodney, 956 F2d 295 (DC Cir 1992). 


\section{CONCLUSION}

The philosophy of legal realists was that judges reasoned backward from result to rationale, selecting rules and facts to fit into a preordained pattern. In appellate courts, it doesn't happen quite like that: there are judges of other persuasions to brake the momentum; there are precedents galore that must be acknowledged and accommodated; there is always the judge's own sense of integrity toward the development of coherent law. But within those constraints, judges still use rhetoric to maneuver. The way they present the facts, the way they describe rules and standards of review, the way they "handle" precedent, their decisions to write separately or stay with the pack, all provide wide avenues in which to drive the law forward. A judge's individual skill at working these levers of power, and doing so in a way that does not overly antagonize colleagues, continues to have a powerful influence on decision making. That is why, in the end, judges-as well as their words-matter so much. 
